\title{
Effect of the amount of concentrate offered in an automated milking system on dry matter intake, milk yield, milk composition, ruminal digestion, and behavior of primiparous Holstein cows fed isocaloric diets
}

\author{
K. S. Paddick, ${ }^{1}$ T. J. DeVries, ${ }^{2}$ K. Schwartzkopf-Genswein, ${ }^{3}$ M. A. Steele, ${ }^{4}$ M. E. Walpole,${ }^{5}$ and G. B. Penner ${ }^{1 *}$ \\ ${ }_{1}^{1}$ Department of Animal and Poultry Science, University of Saskatchewan, Saskatoon, SK, Canada S7N 5A8 \\ ${ }^{2}$ Department of Agricultural, Food and Nutritional Science, University of Guelph, Guelph, ON, Canada N1G 2W1 \\ ${ }^{3}$ Lethbridge Research and Development Centre, Agriculture and Agri-Food Canada, Lethbridge, AB, Canada T1J 4B1 \\ ${ }^{4}$ University of Alberta, Edmonton, AB, Canada T6G 2P5 \\ ${ }^{5}$ DairySmart Nutrition Group, Crediton, ON, Canada NOM 1M0
}

\section{ABSTRACT}

The objective of this study was to determine if the quantity of concentrate provided in an automated milking system (AMS) affects dry matter intake (DMI), attendance to the AMS, milk and milk component yield, feeding behavior, cow activity, and ruminal fermentation of lactating dairy cows fed isocaloric diets. Eight ruminally cannulated primiparous Holstein cows were used in a replicated $4 \times 4$ Latin square design with 28 -d periods. Cows were housed in a freestall facility with a guided-traffic (feed-first) flow barn design. Treatments included $0.5,2.0,3.5$, or $5.0 \mathrm{~kg} / \mathrm{d}$ of dry matter of pellet in the AMS with an equivalent reduction of the same pellet in the partial mixed ration (PMR). Days 21 to 24 of each treatment period were used for DMI, milking performance (visits, yield, and composition), behavior, and ruminal $\mathrm{pH}$ determination, and d 25 to 28 were used for ruminal short-chain fatty acid and ammonia concentrations as well as total-tract digestibility. As imposed, consumption of AMS pellet linearly increased, equating to $0.50,2.00,3.49$, and $4.93 \mathrm{~kg}$ of dry matter/d for the $0.5,2.0,3.5$, and $5.0 \mathrm{~kg} / \mathrm{d}$ treatments, respectively. Correspondingly, the standard deviation in AMS pellet intake among days linearly increased from 0.06 to $0.85 \mathrm{~kg}$ of dry matter/d as the quantity of concentrate in the AMS increased from 0.5 to $5.0 \mathrm{~kg}$. The PMR DMI decreased linearly with increasing AMS concentrate allocation, but total DMI (PMR + AMS) was not affected $(25.3 \mathrm{~kg} / \mathrm{d})$. As the AMS concentrate allocation increased, the selection against particles retained on an 18-mm sieve linearly increased and selection against particles retained on the pan decreased. Milking frequency (3.22 milkings/d), milk yield (37.5

Received May 31, 2018.

Accepted November 28, 2018.

*Corresponding author: greg.penner@usask.ca $\mathrm{kg} / \mathrm{d})$, milk fat yield $(1.43 \mathrm{~kg} / \mathrm{d})$, and milk protein yield $(1.22 \mathrm{~kg} / \mathrm{d})$ were not affected; however, milk urea nitrogen concentration decreased linearly with increasing AMS concentrate. Ruminal $\mathrm{pH}$ averaged 6.18 and was not affected by AMS concentrate. Total ruminal short-chain fatty acid concentration was greatest when $3.5 \mathrm{~kg}$ of concentrate was allocated in the AMS and ruminal ammonia decreased linearly with increasing AMS concentrate. Time spent lying, the number of lying bouts, and average bout duration were not affected by treatment. These data indicate that increasing the quantity of concentrate in the AMS increases daily variability in AMS concentrate intake while decreasing PMR intake without affecting voluntary visits to the AMS and milk or milk component yield. As such, under isocaloric dietary settings, increasing the supply of pellet in the AMS is not likely to affect voluntary visits to the AMS, milk and milk component yields, or ruminal fermentation.

Key words: automatic milking system, concentrate, feeding management, partial mixed ration

\section{INTRODUCTION}

Achieving efficient production with automated milking system (AMS) requires frequent voluntary visits. It is thought that providing palatable concentrates in the AMS motivates voluntary attendance (Prescott et al., 1998); however, feeding management for AMS cows must consider both the AMS concentrate and the partial mixed ration (PMR), as both can affect production outcomes (Menajovsky et al., 2018). Nevertheless, with AMS, feeding management strategies that stimulate voluntary attendance (Wagner-Storch and Palmer, 2003), increase milking frequency (Bach et al., 2007), and result in greater milk yield are necessary (Tremblay et al., 2016; Bach and Cabrera, 2017). Although AMS adoption is increasing (Tse et al., 2017), few controlled studies have evaluated feeding management strategies. 
Of the published studies, most have only evaluated AMS concentrate provision (Halachmi et al., 2005; Tremblay et al., 2016). The sole focus on AMS concentrate has been based on the premise that increasing the quantity of concentrate may enhance voluntary visits to the AMS and may allow for precision feeding strategies (Bach and Cabrera, 2017). A focus on AMS concentrate has enabled collection and publication of survey data comparing producer practices. For example, one study examined 10 US and 15 Canadian AMS farms and determined that $78 \%$ of farms offered less and $22 \%$ of farms offered greater than $5.0 \mathrm{~kg} / \mathrm{cow}$ per day of concentrate in the AMS on an as-fed basis (de Jong et al., 2003). More recently, Tremblay et al. (2016) evaluated data from 635 North American AMS farms (primarily free-flow traffic) and reported that cows were offered $0.16 \mathrm{~kg}$ of concentrate $/ \mathrm{kg}$ of milk produced (as-fed basis). Salfer and Endres (2014) reported that producers were programming concentrate delivery in the AMS ranging from 0.9 to $11.3 \mathrm{~kg}$ (freeflow traffic) or 0.9 to $8.2 \mathrm{~kg}$ (guided or forced-flow) of concentrate per cow per day on an as-fed basis. Feeding large quantities $(>5.0 \mathrm{~kg})$ of concentrate in the AMS is believed to improve milk yield and milk composition due to increased visits from increased motivation to attend the AMS. Whereas survey data provide useful information of current production practices, results are association-based and cannot be used to compare or derive feeding management strategies.

Despite the commercial practice to feed large quantities of concentrate in the AMS, most controlled studies evaluating concentrate provision in the AMS have not supported the suggestion that increasing the quantity of concentrate in the AMS will improve voluntary visits or milk and milk component yield (Bach et al., 2007; Hare et al., 2018). However, Henriksen et al., (2018) reported increased milk yield with increased concentrate allocation, and Menajovsky et al. (2018) reported a tendency for increased milk yield. Past research has also demonstrated that attempts to increase AMS concentrate provision are often unsuccessful, as the targeted AMS concentrate amounts are seldom achieved. Bach et al. (2007) targeted either 3.0 or $8.0 \mathrm{~kg} / \mathrm{d}$ of concentrate in the AMS; however, only 2.6 and $6.8 \mathrm{~kg}$ of $\mathrm{DM} / \mathrm{d}$ of concentrate were achieved. Similarly, Halachmi et al. (2005) targeted $1.2 \mathrm{~kg}$ of concentrate per milking or $7.0 \mathrm{~kg} / \mathrm{d}$ of concentrate in the AMS and achieved 3.5 and $5.2 \mathrm{~kg}$ of $\mathrm{DM} / \mathrm{d}$, respectively. Henriksen et al. (2018) targeted 3 and $8 \mathrm{~kg}$ of DM and only achieved 2.2 and $4.4 \mathrm{~kg}$ of DM for Holstein cows. The discrepancy between the targeted quantity of AMS concentrate and that consumed suggests that cows were not consuming the formulated diet. Moreover, as AMS concentrate intake increases, PMR intake decreases in an unpredictable manner. Bach et al. (2007), in a free-flow design, and Hare et al. (2018) and Menajovsky et al. (2018), both in guided-flow systems, determined that for every $1 \mathrm{~kg}$ increase in concentrate consumed in the AMS, PMR intake was reduced by $1.14,1.58$, and $0.84 \mathrm{~kg}$ of DM, respectively. Continued research is needed to understand how AMS and PMR formulation strategies affect intake of dietary components (PMR and AMS) and production responses.

We hypothesized that increasing the quantity of concentrate in the AMS would reduce PMR consumption and increase variability in ruminal $\mathrm{pH}$ without affecting voluntary attendance to the AMS or milk and milk component yield. The objective of our study was to evaluate whether AMS concentrate allocation affects PMR DMI, voluntary attendance to the AMS, feeding behavior, cow activity, ruminal fermentation, totaltract digestibility, and milk and milk component yield under isonutrient dietary settings.

\section{MATERIALS AND METHODS}

\section{Animal Husbandry and Experimental Design}

Our study took place at the University of Saskatchewan Rayner Dairy Research and Teaching Facility (Saskatoon, SK, Canada). Eight primiparous Holstein cows, previously fit with a silicone elastomer ruminal cannula (Robyn Williams, Mount Evelyn, Victoria, Australia), were used in a replicated $4 \times 4$ Latin square design. All animal use was preapproved by the University of Saskatchewan Research Ethics Board (protocol \#20100021). At the start of the study cows averaged (mean $\pm \mathrm{SD}$ ) $90.6 \pm 9.8 \mathrm{DIM}$ and the 7 -d milk yield before starting the study was $37.9 \pm 6.0 \mathrm{~kg} / \mathrm{d}$. Cows were housed in a freestall barn with 12 stalls and the barn was designed as a feed-first guided-traffic flow design with an AMS (DeLaval, Tetra Laval Group, Tumba, Södermanland, Sweden). The total number of cows (study cows and nonstudy cows) milked by the AMS at any given time throughout the experiment was between 30 and 40 cows and the AMS averaged 120.7 milkings/d throughout the duration of the study. The cows on the study had a separate feed and stall area from the cows not on the study; however, all cows shared a similar AMS holding area. All study cows had permission to enter the AMS every $4 \mathrm{~h}$ or if the predicted milk yield was greater than $9.0 \mathrm{~kg}$. A one-way gate prevented cows from entering the freestall once in the feed bunk area. The feed bunk area contained 8 Insentec Feed Bunks (Hokofarm Group, Marknesse, Flevoland, the Netherlands) with an individual cow 
assigned to each bunk. Cows were trained to use the Insentec bunks and AMS 6 wk before the start of the study. For cows to return to the freestall area from the feed bunk area, they had to pass through a preselection sort-gate. This gate directed cows toward the AMS when milking permission was granted or toward the freestall area when milking permission criteria were not met. If cows did not voluntarily enter the milking stall within $12 \mathrm{~h}$, they were fetched and placed in the holding pen to be milked. Fetching times were restricted to 0400, 1030, 1730, and $2230 \mathrm{~h}$ daily and fetching activity was recorded; however, only 1 cow in 2 periods required fetching for 2 milking events.

Within each Latin square, cows were randomly assigned to 1 of 4 treatments with the sequence of treatments balanced to avoid carryover effects. Periods were designed to consist of $19 \mathrm{~d}$ for dietary adaptation ( 1 to 19 of each period); $4 \mathrm{~d}$ for measurement of feeding behavioral measurements, DMI, milk and milk component yield, and cow activity data collection (d 20 to 23 for each period); $1 \mathrm{~d}$ for device removal ( $\mathrm{d} 24$; indwelling $\mathrm{pH}$ loggers and accelerometers were removed from cows); and $4 \mathrm{~d}$ for measurement of ruminal fermentation and total-tract digestibility (d 25 to 28 of each period). Day 19 of each period was used for placement of indwelling $\mathrm{pH}$ loggers and accelerometers, as discussed later. Periods were designed to be $28 \mathrm{~d}$ in duration; however, periods 2, 3, and 4 were extended because the AMS required repairs during collection periods. As such, the actual duration of periods $1,2,3$, and 4 were $28,30,32$, and $40 \mathrm{~d}$, respectively. Despite the extended periods, all data collected allowed for 4 consecutive days of behavioral measurements and 4 consecutive days for ruminal fermentation and total-tract digestibility, as originally planned, with the adaptation phase extended.

\section{Feeding Management and Experimental Treatments}

Diets were formulated to be equal in macro- and micronutrient provision. As such, cows in each treatment received the same total dietary nutrient provision when considering the sum of the PMR and the AMS concentrate. Thus, treatment groups differed in the amount of concentrate allocated in the AMS, with targets of $0.5,2.0,3.5$, or $5.0 \mathrm{~kg} / \mathrm{d}$ (DM basis; Table 1). As the AMS concentrate target increased, an equal and corresponding quantity of concentrate offered in the PMR decreased. To avoid confounding effects, the pellet provided in the AMS was the same as that offered in the PMR (Table 2) and the forage-to-concentrate ratio $(\mathbf{F}: \mathbf{C})$ for each treatment (AMS concentrate + PMR) was 54.5:45.6. However, the F:C of the PMR for the $0.5,2.0,3.5$, and $5.0 \mathrm{~kg}$ concentrate allocation in the AMS were 55.5:44.4, 59.5:40.5, 64.1:35.9, and 69.4:30.6, respectively. Diets were formulated for a $580-\mathrm{kg}$ cow with an expected milk yield of $36 \mathrm{~kg}$ containing $4 \%$ fat and $3.2 \%$ protein using the Cornell Net Carbohydrate and Protein System (6.55) platform of NDS (The RUM\&N Company, Reggio Emilia, Italy).

Cows were provided their PMR in Insentec Feed Bunks (Hokofarm Group), with 1 cow assigned to each bunk to allow for measurement of PMR intake and feeding behavior. Ingredients for the PMR were loaded and mixed using a ValMetal (MW-270, ValMetal, Saint-Germain-de-Grantham, Quebec, Canada) TMR wagon. For each respective PMR, a portion of the basal mix was dispensed into a data ranger (Calan Super Data Ranger, American Calan Inc., Northwood, $\mathrm{NH}$ ) and the PMR pellet was added and mixed. The PMR was fed twice daily, with $60 \%$ of the daily PMR allowance provided at $1100 \mathrm{~h}$ and $40 \%$ at $2230 \mathrm{~h}$. The quantity of PMR refused was recorded at $1030 \mathrm{~h}$ daily and refusals were removed from the feed bunk. The PMR was provided for ad libitum consumption with refusals targeted to be between 5 and 10\% (as is basis) of the total PMR offered. To ensure each treatment contained the targeted $\mathrm{F}: \mathrm{C}$, forage components were sampled twice weekly, and concentrate components were sampled once weekly. Samples were used for DM determination (described below) and DM coefficients were updated as necessary.

To achieve the specified DM provision of the AMS concentrate, the amount of concentrate offered in the AMS was monitored daily and adjustments were made every fourth day based on the average intake of the previous $3 \mathrm{~d}$. The amount of AMS concentrate eligible for each cow exceeded the target $(0.51,2.02,3.52$, and $5.03 \mathrm{~kg}$ for the $0.5,2.0,3.5$, and $5.0 \mathrm{~kg} / \mathrm{d}$ treatments, respectively, on a DM basis) to ensure that the target AMS consumption was achieved. The AMS feeder was calibrated weekly; at each calibration, the AMS feeder was cleaned and 4 calibration samples were obtained directly from the feeder. The first sample was discarded to ensure material dislodged during the cleaning process did not affect the calibration outcome. The last 3 samples were weighed and an average of the 3 weights were entered into the computer system (Delpro 4.5 , DeLaval). The amount of AMS pellet offered was recorded by the software (Delpro 4.5) and was assumed to equal the amount consumed. To ensure cows were receiving their designated AMS concentrate allocation, the AMS feeder was cleaned 4 times daily during the collection days to minimize the quantity of refusals of AMS concentrate from cows milked previously. In addition, cows that were milked on the AMS but were not on the study received $1.1 \mathrm{~kg}$ of AMS pellet (DM basis) to reduce likelihood of refused concentrate in the AMS. 
Table 1. Ingredient and chemical composition of the total diets [partial mixed ration (PMR) + automatic milking system (AMS) concentrate] used to test whether the location of concentrate provision affects DMI, milk production, ruminal fermentation, and cow behavior

\begin{tabular}{|c|c|c|c|c|}
\hline \multirow[b]{2}{*}{ Variable } & \multicolumn{4}{|c|}{ Quantity of concentrate in the AMS, $\mathrm{kg} / \mathrm{d}$} \\
\hline & 0.5 & 2.0 & 3.5 & 5.0 \\
\hline \multicolumn{5}{|l|}{ Ingredient, $\%$ of $\mathrm{DM}$} \\
\hline Barley silage & 37.0 & 37.0 & 37.0 & 37.0 \\
\hline Alfalfa hay & 17.4 & 17.4 & 17.4 & 17.4 \\
\hline Barley grain & 15.2 & 15.2 & 15.2 & 15.2 \\
\hline PMR pellet ${ }^{1}$ & 27.0 & 20.4 & 13.9 & 7.4 \\
\hline Palmitic acid $^{2}$ & 1.3 & 1.3 & 1.3 & 1.3 \\
\hline AMS pellet ${ }^{1}$ & 2.2 & 8.7 & 15.2 & 21.7 \\
\hline \multicolumn{5}{|l|}{ Chemical composition $^{3}$} \\
\hline DM, \% & 62.3 & 62.6 & 62.5 & 62.2 \\
\hline $\mathrm{OM}, \%$ of $\mathrm{DM}$ & 92.3 & 92.3 & 92.3 & 92.3 \\
\hline $\mathrm{CP}, \%$ of $\mathrm{DM}$ & 17.5 & 17.5 & 17.5 & 17.5 \\
\hline $\mathrm{aNDF}_{\mathrm{OM}},{ }^{4} \%$ of $\mathrm{DM}$ & 30.5 & 30.4 & 30.4 & 30.4 \\
\hline $\mathrm{ADF}, \%$ of $\mathrm{DM}$ & 19.8 & 19.8 & 19.8 & 19.8 \\
\hline Starch, \% of DM & 25.4 & 25.5 & 25.5 & 25.5 \\
\hline Ether extract, $\%$ of DM & 4.9 & 4.9 & 4.9 & 4.9 \\
\hline $\mathrm{Ca}, \%$ of $\mathrm{DM}$ & 0.9 & 0.9 & 0.9 & 0.9 \\
\hline $\mathrm{P}, \%$ of $\mathrm{DM}$ & 0.4 & 0.4 & 0.4 & 0.4 \\
\hline $\mathrm{NE}_{\mathrm{L}}, \mathrm{Mcal} / \mathrm{kg}$ & 1.69 & 1.72 & 1.72 & 1.72 \\
\hline
\end{tabular}

${ }^{1}$ The pellet was supplied by the Canadian Feed Research Centre (North Battleford, SK, Canada); it contained calcium (1.5\%), phosphorus (0.8\%), magnesium (0.6\%), potassium $(1.0 \%)$, sodium $(1.1 \%)$, chlorine $(1.0 \%)$, sulfur $(0.7 \%)$, manganese $(5.4 \mathrm{mg} / \mathrm{kg})$, copper $(24 \mathrm{mg} / \mathrm{kg})$ iron $(179 \mathrm{mg} / \mathrm{kg})$, zinc $(39 \mathrm{mg} / \mathrm{kg})$, iodine $(2.1$ $\mathrm{mg} / \mathrm{kg})$, cobalt $(0.1 \mathrm{mg} / \mathrm{kg})$, selenium $(0.8 \mathrm{mg} / \mathrm{kg})$, vitamin A $(11,484 \mathrm{IU} / \mathrm{kg})$, vitamin D $(4,489 \mathrm{IU} / \mathrm{kg})$, and vitamin E $(98.4 \mathrm{IU} / \mathrm{kg})$.

${ }^{2}$ Source of palmitic acid was Energizer Rumen Protected (RP10; Scothorn Nutrition, Grand Pré, NS, Canada).

${ }^{3}$ Average of the chemical composition from the metabolic measurement phase from each period.

${ }^{4} \mathrm{aNDF}_{\mathrm{OM}}=\mathrm{NDF}$ treated with amylase and sodium sulfite and corrected for ash content.

\section{Data and Sample Collection}

The BW of each cow was measured on 2 consecutive days at the start of each period and at the end of the final period. Body weight was measured $(0730 \mathrm{~h})$ before the PMR feeding; however, it is important to note that time since milking and the last AMS concentrate meal varied. An average of the $2 \mathrm{BW}$ measurements

Table 2. Ingredient and chemical composition of the pellet used in the automatic milking system (AMS) and partial mixed ration (PMR)

\begin{tabular}{lc}
\hline Inclusion rate, $\%$ & AMS and PMR pellet \\
\hline Canola meal & 29.17 \\
Corn grain & 22.86 \\
Soybean meal & 17.32 \\
Peas & 13.44 \\
Soybean hulls & 5.89 \\
Urea & 0.36 \\
Fat canola oil & 2.71 \\
Premix & 8.25
\end{tabular}

${ }^{1}$ The premix was supplied by the Canadian Feed Research Centre (North Battleford, SK, Canada); it contained calcium (12.6\%), phosphorus (1.8\%), magnesium (4.1\%), potassium (0.05\%), sodium $(12.4 \%)$, chlorine $(10.0 \%)$, sulfur $(4.2 \%)$, manganese $(30 \mathrm{mg} / \mathrm{kg})$, copper $(248 \mathrm{mg} / \mathrm{kg})$, iron $(1,635 \mathrm{mg} / \mathrm{kg})$, zinc $(364 \mathrm{mg} / \mathrm{kg})$, iodine $(23$ $\mathrm{mg} / \mathrm{kg})$, cobalt $(1 \mathrm{mg} / \mathrm{kg})$, selenium $(8 \mathrm{mg} / \mathrm{kg})$, vitamin A $(126,801$ $\mathrm{IU} / \mathrm{kg})$, vitamin D $(49,592 \mathrm{IU} / \mathrm{kg})$, and vitamin $\mathrm{E}(1,088 \mathrm{IU} / \mathrm{kg})$. was calculated. Body condition score was collected independently by 3 trained personnel on d 1 of each period and at the end of the last period using the 5-point scale described by Wildman et al. (1982). The individual scores were averaged to yield the value used for statistical analysis.

Feed intake, on an as-fed basis, was recorded daily throughout the experiment. Data collected during the 4 -d behavioral measurement phase and the 4-d ruminal fermentation and digestibility measurement phases were used for determination of PMR DMI. The DM of the PMR and the PMR chemical composition were calculated based on the proportional inclusion rate of individual ingredients and the measured DM and chemical composition of those ingredients. Ingredients were collected daily, pooled equally among days to create a composite, and used for DM determination. The silage sampling procedure involved collection of grab samples located throughout the face of the silage pit. The sample was mixed, and a 1-kg subsample was used for DM determination. Hay samples were collected from a pile of ground hay with grab samples taken from numerous regions of the pile. The individual grab samples within commodity type were composited, mixed, and subsampled. In addition, a 750-g sample was collected from each of the concentrates used in the 
diets. Samples were stored in a freezer at $-20^{\circ} \mathrm{C}$. Refusals were collected for each cow individually on daily basis and were composited proportionally before DM analysis. The composited feed ingredient and refusal samples collected during the 4-d behavioral measurement period were used to determine DM and particle size distribution (Kononoff et al., 2003; described below). Composited ingredient and refusals samples from the ruminal fermentation and digestibility phase were analyzed for DM and chemical analysis (Table 3). Dry matter was determined by placing a 500-g sample into a forced-air oven at $55^{\circ} \mathrm{C}$ until the weight was constant. Subsequently, concentrate samples were ground through a 1-mm sieve using an Ultra Centrifugal Mill Type ZM 200 (Retsch GmbH \& Co. KG, Haan, North Rhine-Westphalia, Germany), whereas silage and hay samples were ground using a Christy Norris grinder (Christy Norris Ltd., Chelmsford, UK) equipped with a 1-mm sieve. The ground composites from the ruminal fermentation and digestibility phase were sent to Cumberland Valley Analytical (CVAS Ltd., Waynesboro, $\mathrm{PA}$ ) for analysis of DM, OM, CP, NDF, NDF with the addition of sodium sulfite and $\alpha$-amylase corrected for ash $\left(\mathbf{a N D F} \mathbf{F M}_{\mathbf{O M}}\right), \mathrm{ADF}$, ether extract, starch, undigested aNDFom after $240 \mathrm{~h}$ of in vitro digestion $\left(\mathrm{uNDF}_{\mathrm{OM}}\right)$, $\mathrm{Ca}$, and P. Analyses were completed as explained below.

Milk and Milk Component Yield. Milk yield was measured during the behavioral collection phase of each period using the AMS along with DelPro 4.5 (DeLaval). The average milk yield across the 4-d collection period was used. In addition, the milk yield per visit, number of visits, milking duration (box-time), incomplete milkings on each quarter, quarters where the milker was kicked off, and milkings where the milking machine was unable to find teats were recorded. Samples from each milking for each cow from the 4-d behavioral collection period were obtained via a sampling system connected to the AMS and a daily 40-mL composite (proportional to yield) was prepared for each cow in containers containing a Bronopol Microtab preservative (Dairy Herd Improvement Laboratory, Edmonton, Alberta, Canada). To minimize the duration samples were sitting at barn temperature, samples were retrieved from the sampling device every $4 \mathrm{~h}$ and transferred to a refrigerator for storage at $4^{\circ} \mathrm{C}$. After compositing, daily milk samples were sent to the Dairy Herd Improvement Laboratory for analysis of protein, fat, lactose, SCC, TS, and MUN. Fat, protein, lactose, TS, and MUN were determined using mid-infrared spectroscopy, whereas SCC was determined using flow cytometry. Samples were stored at $4^{\circ} \mathrm{C}$ before submission.

Feeding Behavior Responses. The Insentec feed bunks that contained the PMR were connected and controlled via computer software (RIC Management Software, The Hokofarm Group). The software recorded the date, time, duration, and size of each PMR visit for each cow during the behavioral measurement phase within each period. These data were processed to remove visits to the feed bunk where no feed was consumed. The intermeal intervals between each visit were then calculated and $\log _{10}$ transformed (Tolkamp et al., 1998). The transformed data were fit to normal distributions to determine appropriate meal criteria for each cow within each period using the procedure explained by DeVries et al. (2003a) and the MIXDIST package (Macdonald and Green, 1988) of the R Statistical Analysis Software (The R Foundation, Adelaide, South Australia, Australia). The meal criteria were defined as the minimum time interval away from the feed bunk to identify a new meal. These data were then

Table 3. Chemical composition of individual feed ingredients

\begin{tabular}{|c|c|c|c|c|c|c|}
\hline \multirow[b]{2}{*}{$\begin{array}{l}\text { Chemical } \\
\text { composition }^{1}\end{array}$} & \multicolumn{6}{|c|}{ Dietary ingredient } \\
\hline & $\begin{array}{l}\text { Barley } \\
\text { silage }\end{array}$ & $\begin{array}{l}\text { Alfalfa } \\
\text { hay }\end{array}$ & $\begin{array}{l}\text { Barley } \\
\text { grain }\end{array}$ & $\begin{array}{l}\text { Palmitic } \\
\text { acid }^{2}\end{array}$ & $\begin{array}{l}\text { AMS } \\
\text { pellet }^{3}\end{array}$ & $\begin{array}{l}\text { PMR } \\
\text { pellet }^{3}\end{array}$ \\
\hline DM, \% & 42.16 & 84.14 & 86.45 & 99.94 & 89.69 & 89.30 \\
\hline $\mathrm{OM}, \%$ of $\mathrm{DM}$ & 93.28 & 90.67 & 97.39 & 99.49 & 89.12 & 89.14 \\
\hline $\mathrm{CP}, \%$ of $\mathrm{DM}$ & 11.78 & 18.5 & 11.50 & 0.20 & 28.08 & 28.13 \\
\hline $\mathrm{aNDF}_{\mathrm{OM}},{ }^{4} \%$ of DM & 40.10 & 41.93 & 21.08 & 1.23 & 17.30 & 17.60 \\
\hline $\mathrm{ADF}, \%$ of $\mathrm{DM}$ & 24.78 & 34.83 & 8.13 & 0.28 & 11.28 & 11.68 \\
\hline Starch, \% of DM & 25.13 & 1.78 & 59.90 & 0.08 & 23.53 & 23.05 \\
\hline Ether extract, $\%$ of DM & 3.82 & 1.98 & 2.19 & 98.43 & 5.26 & 5.33 \\
\hline $\mathrm{Ca}, \%$ of DM & 0.33 & 1.28 & 0.07 & 0.003 & 1.79 & 1.80 \\
\hline $\mathrm{P}, \%$ of $\mathrm{DM}$ & 0.26 & 0.26 & 0.34 & 0.00 & 0.74 & 0.74 \\
\hline
\end{tabular}


used to determine the number of meals (no./d), length of meals ( $\mathrm{min} / \mathrm{meal})$, size of meals $(\mathrm{kg})$, and rate of consumption $(\mathrm{kg} / \mathrm{min})$ using the procedure explained in Tolkamp et al. (1998). Once the daily determination of each variable was calculated, values were averaged among the 4-d behavior collection period.

Feed sorting behavior was analyzed during the behavioral measurement period of each treatment period. Partial mixed ration sorting behavior was measured with the Penn State Particle Separator (PSPS), using the procedure described by Leonardi and Armentano (2003). Briefly, all particle size measurements were conducted in duplicate (for each ingredient and refusals) for the composited samples according to Kononoff et al. (2003), using the PSPS with aperture openings of 19, 8 , and $4 \mathrm{~mm}$, with the remaining material caught on a pan. To determine the sorting index, the consumption of particles retained on each sieve of the PSPS was determined by calculating the difference between the amounts offered and refused. The actual consumption was divided by the theoretical consumption of each particle size fraction assuming no sorting. The values were then expressed as a percentage, where a sorting index of 100 indicates no selective behavior for that particle length, a sorting index of greater than 100 indicates sorting for that particle length, and a sorting index of less than 100 indicates sorting against that particle length (Leonardi and Armentano, 2003). The sorting index allows for an understanding of whether cows are selectively consuming or avoiding portions of their PMR (Miller-Cushon and DeVries, 2017).

Cow-Activity Budget Responses. Accelerometers (HOBO Pendant G Data Logger, Onset Computer Corporation, Bourne, MA) were placed on the hind right leg of each cow the day before the start of the behavioral phase, with placement following the protocol described by Zobel and Chapinal (2013). Devices were removed after $4 \mathrm{~d}$ of continuous data collection for each period and the data were downloaded onto a computer. The number of standing and lying bouts and the duration of each bout were determined using SAS (version 9.3; SAS Institute Inc., Cary, NC), as described by Zobel and Chapinal (2013) with the algorithms of Ledgerwood et al. (2010). Data were summarized by cow and period.

Ruminal Fermentation and Total-Tract Digestibility. Ruminal $\mathrm{pH}$ was measured during the behavioral measurement phase of each period to ensure that ruminal $\mathrm{pH}$ values were not affected by the ruminal digesta sampling protocols (described below) and resulting changes in activity. Ruminal $\mathrm{pH}$ was measured using the Lethbridge Research Centre Ruminal pH Measurement System (LRCpH; Penner et al., 2006). The $\mathrm{LRCpH}$ was inserted through the ruminal cannula into the ventral sac of the rumen to enable 96 consecutive hours of ruminal $\mathrm{pH}$ data collection. The LRCpH was programmed to log data every $1 \mathrm{~min}$. Before insertion into the rumen and following removal from the rumen, the $\mathrm{LRCpH}$ was maintained at $39^{\circ} \mathrm{C}$ for standardization in $\mathrm{pH}$ buffers 7 (RICCA Chemical Company, Arlington, TX) and 4 (Fisher Chemical, Battle Ground, WA). Upon retrieving the $\mathrm{LRCpH}$, millivolt data were downloaded to a computer. The relationship between millivolts and $\mathrm{pH}$ derived from the starting and ending standardizations were used to convert the recorded millivolt values to $\mathrm{pH}$ units, assuming a linear offset between the starting and ending regressions. Data were summarized to determine the daily minimum, mean, and maximum $\mathrm{pH}$, duration that $\mathrm{pH}$ was less than 5.8 , and area when $\mathrm{pH}$ was less than 5.8 , as described by Penner et al. (2007).

Ruminal digesta and fecal samples were collected over 4 consecutive days during the metabolic phase of each period. Samples were collected at 12-h intervals with a 3 -h offset among days to represent a 24-h cycle. At each time point, $250-\mathrm{mL}$ of ruminal digesta were collected from the cranial, central, and caudal regions of the rumen fluid/rumen mat interface. The mixed digesta $(750 \mathrm{~mL})$ was strained through 2 layers of cheesecloth, filtrate was mixed, and subsamples of ruminal fluid filtrate were obtained. One $10-\mathrm{mL}$ sample was added to a $15-\mathrm{mL}$ vial with $2 \mathrm{~mL}$ of $25 \%$ meta-phosphoric acid for the analysis of short-chain fatty acid (SCFA) concentration; the second $10-\mathrm{mL}$ sample was added to a $15-\mathrm{mL}$ vial with $2 \mathrm{~mL}$ of sulfuric acid that was subsequently analyzed for ammonia concentration. These samples were sealed and stored at $-20^{\circ} \mathrm{C}$ until analysis.

Corresponding to the time of ruminal fluid sampling, $200 \mathrm{~g}$ of feces were collected directly from the rectum of each cow. Following collection, the fecal sample was thoroughly mixed and $125 \mathrm{~g}$ was added at each collection time point to a plastic container to form a 1,000-g composite per cow. The fecal samples were stored at $-20^{\circ} \mathrm{C}$ until thawed to prepare duplicate 500 -g samples. These duplicate samples were placed in a $55^{\circ} \mathrm{C}$ forcedair oven to determine DM, as described for feed samples. Fecal samples were then ground using the Ultra Centrifugal Mill ZM 100 grinder (Retsch GmbH \& Co. $\mathrm{KG}$ ) to pass through a $1-\mathrm{mm}$ sieve. The ground samples were sent to Cumberland Valley Analytical Services for determination of $\mathrm{DM}, \mathrm{OM}, \mathrm{CP}, \mathrm{aNDF}_{\mathrm{OM}}, \mathrm{ADF}$, starch, ether extract, indigestible NDF, and ethanol-soluble carbohydrates (described below).

\section{Sample Analyses}

Feed samples collected during the behavioral phase (d 20-23) and the feed, refusal, and fecal samples from the metabolic phase (d 25-28) were dried and ground 
(previously described) to pass through a 1-mm sieve. Forage samples were dried at $105^{\circ} \mathrm{C}$ for $3 \mathrm{~h}$ (National Forage Testing Association, 2006) and concentrate samples and palmitic acid were analyzed for DM by drying in an oven at $135^{\circ} \mathrm{C}$ for $2 \mathrm{~h}$ (method 930.15 , AOAC International, 2000). Crude protein was analyzed by nitrogen combustion (method 990.03, AOAC International, 2000) with a Leco FP-528 Nitrogen Combustion Analyzer (Leco Corp., St. Joseph, MI). Neutral detergent fiber and ADF were analyzed using Whatman 934-AH glass microfilters (GE Healthcare Life Sciences, Mississauga, ON, Canada) with 1.5-um particle retention (method 973.18, AOAC International, 2000). The $\mathrm{NDF}$ analysis was conducted with $\mathrm{aNDF}_{\mathrm{OM}}$ by ashing the sample in a furnace $\left(535^{\circ} \mathrm{C}\right)$ for $2 \mathrm{~h}$. Indigestible $\mathrm{NDF}$ was determined by measuring the remaining NDF after $240 \mathrm{~h}$ of incubation in ruminal fluid in vitro (Cumberland Valley Analytical Services Inc., 2018). Samples from the behavioral phase were used to determine diet composition for d 20 to 23, whereas samples from the metabolic phase were used for diet composition and nutrient digestibility determination. Ether extract was analyzed (method 2003.05, AOAC International, 2006) using a Tecator Soxtec System HT 1043 extraction unit (Tecator, Foss NA, Eden Prairie, MN). Starch was analyzed using the method described by Hall et al. (1999). Ash was analyzed by heating a 1.5 -g sample to $550^{\circ} \mathrm{C}$ for $4 \mathrm{~h}$ (method 942.05, AOAC International, 2000) and OM was calculated by subtracting the ash concentration from $100 \%$. Calcium was determined using a dry-ash procedure (method 927.02, AOAC International, 2000) followed by atomic absorption (model 2380, PerkinElmer, Waltham, MA). Phosphorus was determined using a dry-ash procedure (method 965.17, AOAC International, 2000), and concentration was read on a spectrometer at $410 \mathrm{~nm}$ (Pharmacia, LKB-Ultrasepc III, Stockholm, Södermanland, Sweden). Results from the individual commodity samples collected during the metabolic collection period were used to calculate the composition of the diet (Table 1).

Ruminal fluid samples, preserved with $25 \%$ metaphosphoric acid, were thawed over night at $4^{\circ} \mathrm{C}$ and composited (equal volume basis) the following morning to yield 1 sample/cow per period. Sample preparation for gas chromatography followed the protocol described by Khorasani et al. (1996). The concentration of SCFA was measured using an Agilent gas chromatograph (6890 series with FID, Agilent Technologies Inc., Santa Clara, CA). Samples were injected using a 17:1 split ratio at $170^{\circ} \mathrm{C}$. The column was a Phenom FFAP (Agilent Technologies Inc.) and the initial oven and detector temperatures were $90^{\circ} \mathrm{C}$ and $250^{\circ} \mathrm{C}$, respectively. The oven temperature increased at a constant rate of $10^{\circ} \mathrm{C} /$ min.
Ruminal fluid samples that were frozen with sulfuric acid were thawed overnight at $4^{\circ} \mathrm{C}$. These samples were then composited as described previously for SCFA and analyzed for ammonia- $\mathrm{N}$ using the procedure described by Fawcett and Scott (1960). Briefly, the supernatant from the centrifuged samples were transferred in duplicate into glass test tubes with standard solutions (sodium phenoxide, nitroprusside, and hypochlorite) and a standard curve was prepared using distilled water with the standard solutions. After a 1-h incubation period, these samples were analyzed in a spectrophotometer (SPECTRAmax PLUS ${ }^{384}$, Molecular Devices Corporation, San Jose, CA). The values determined by the spectrometer were used in calculations to determine the concentration of ammonia. If the duplicate samples had greater than a $7 \%$ error, they were prepared and rerun.

\section{Statistical Analysis}

Statistical analyses were completed using the MIXED procedure of SAS 9.4 (SAS Institute Inc.). The model included the fixed effects of treatment and the random effects of period and cow within Latin square. Polynomial contrasts were used to evaluate linear, quadratic, or cubic effects of treatments. The PROC UNIVARIATE (SAS Institute Inc.) procedure was used to determine if the data and residuals were normally, identically, and independently distributed. Data for the standard deviation in PMR and AMS intake did not have equal variance and were analyzed using the GLIMMIX model to account for unequal variance. For the duration and area $\mathrm{pH}$ was below 5.8, the data were log-transformed before analysis. The means and standard error of the means reported were generated before transformation. All other data were normally distributed. Significance was declared when $P \leq 0.05$ and trends were declared at $0.05<P \leq 0.1$.

Data for AMS concentrate intake, PMR intake, and total DMI were also analyzed using repeated measures with the day as the repeated variable. Covariance error structures were tested to determine which yielded lowest Akaike and Bayesian information criterion values. The covariance structure that best suited the data was compound symmetry. The same statistical model was used to evaluate AMS concentrate intake, PMR intake, and total DMI data, with the exception that the model included the fixed effects of day and the day treatment interaction.

A 2-tailed $t$-test was used to evaluate if PMR sorting behaviors were different from 100 for each particle length within each treatment. If the sorting index was greater than 100, this indicated selective sorting for that particle length, whereas a sorting index less than 100 indicated selective avoidance for that particle length. 


\section{RESULTS}

\section{DMI and Feeding Behavior}

The BW $(648 \mathrm{~kg})$ and BCS (3.33) of cows were not affected by treatment $(P \geq 0.22$, Table 4$)$. The quantity of AMS concentrate consumed for each treatment was $0.50,2.00,3.49$, and $4.93 \mathrm{~kg}$ of $\mathrm{DM} / \mathrm{d}\left(P_{\text {linear }}<\right.$ 0.001), with quantities consumed being similar to the targets of $0.5,2.0,3.5$ and $5.0 \mathrm{~kg} / \mathrm{d}$, respectively. As the AMS concentrate allocation increased linearly, AMS concentrate meal sized increased linearly $(P<0.001)$. The standard deviation in AMS concentrate intake across days linearly increased as the quantity offered increased $\left(P_{\text {linear }}<0.001\right)$. Intake of PMR decreased linearly $\left(P_{\text {linear }}<0.001\right)$ as the quantity of concentrate in the AMS increased. The slope of the linear regression between PMR and AMS concentrate intake indicated that, for every $1.00-\mathrm{kg}$ increase in AMS concentrate consumed, PMR intake decreased by $0.97 \mathrm{~kg}$ of DM. The standard deviation of PMR intake across days was not different among treatments $(1.45 \mathrm{~kg} / \mathrm{d} ; P \geq 0.26)$. Total DMI was not affected, averaging $25.3 \mathrm{~kg} / \mathrm{d}(P \geq$ $0.29)$.
The number of PMR meals (6.7 meals/d) and size of PMR meals $(3.48 \mathrm{~kg} / \mathrm{meal})$ did not differ among treatments (Table $4 ; P \geq 0.22$ ). The duration of PMR meals tended to increase linearly $\left(P_{\text {linear }}=0.071\right)$ from 32.3 $\mathrm{min} /$ meal for cows fed $0.5 \mathrm{~kg}$ of concentrate in the AMS to $45.8 \mathrm{~min} / \mathrm{meal}$ for cows fed $5.0 \mathrm{~kg}$ of concentrate. Consumption rate of the PMR linearly decreased from 110 to $84 \mathrm{~g} / \mathrm{min}$ as the AMS concentrate was increased from 0.5 to $5.0 \mathrm{~kg} / \mathrm{d}\left(P_{\text {linear }}<0.001\right)$.

As the quantity of AMS concentrate increased, cows increased their sorting against particles retained on the $19-\mathrm{mm}$ sieve $\left(P_{\text {linear }}=0.015\right)$ and linearly reduced their sorting against particles retained on the pan (Table 4; $\left.P_{\text {linear }}<0.001\right)$. However, based on a 2 -tailed $t$-test, the sorting index was only different from $100 \%$ for cows fed $0.5 \mathrm{~kg} / \mathrm{d}$ in the AMS and particles retained on the bottom pan $\left(80.9 \%, P_{\text {linear }}=0.044\right)$. No other sorting behavior was detected among treatments.

\section{Voluntary Milkings, Milk Yield, and Milk Composition}

Milking frequency (3.2 visits/d), milk yield (37.4 $\mathrm{kg} / \mathrm{d})$, milk fat $(1.43 \mathrm{~kg} / \mathrm{d})$, and milk protein $(1.22$

Table 4. Partial mixed ration (PMR) intake, intake of concentrate in the automated milking system (AMS), total DMI, and feeding behavior of cows fed increasing quantities of concentrate in the AMS with a concurrent and equal reduction of the proportion of concentrate in the PMR

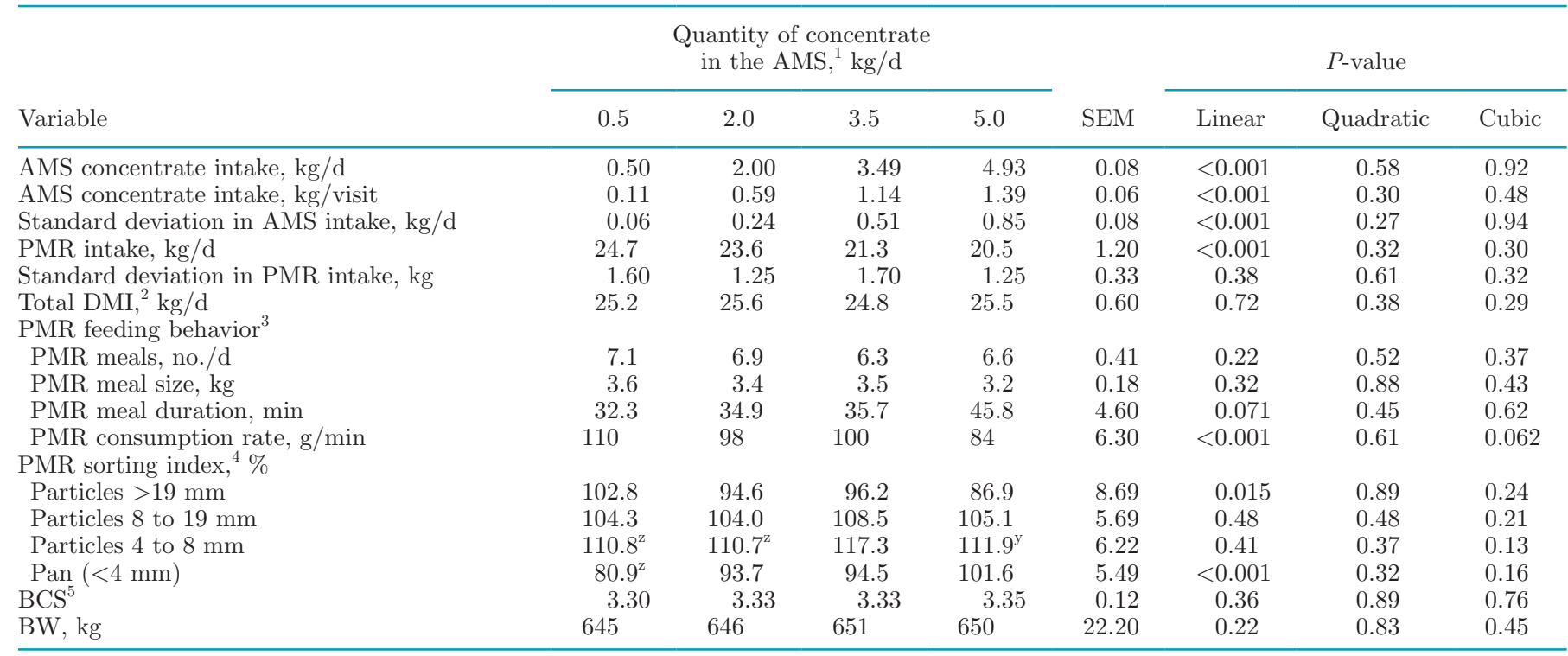

${ }^{\mathrm{z}}$ Significantly different from a sorting index of $100(P \leq 0.05)$.

${ }^{\mathrm{y}}$ Tendency $(P<0.10)$ for the sorting index to be different from 100 .

${ }^{1}$ All diets (AMS concentrate + PMR) were isocaloric. The pellet offered in AMS was the same as the pellet in the PMR.

${ }^{2}$ Total DMI includes PMR and AMS intake.

${ }^{3}$ Calculated using intermeal intervals following procedure in DeVries et al. (2003a).

${ }^{4}$ Sorting index was calculated using description by Leonardi and Armentano (2003). Values greater than 100 indicate selective consumption, whereas those less than 100 indicate selective avoidance.

${ }^{5}$ Body condition was measured using the 5-point scale defined by Wildman et al. (1982). 
Table 5. Milk yield, milking frequency, voluntary attendance, and milk composition for cows fed increasing quantities of concentrate in the automated milking system (AMS) with a concurrent and equal reduction in the proportion of concentrate in the partial mixed ration (PMR)

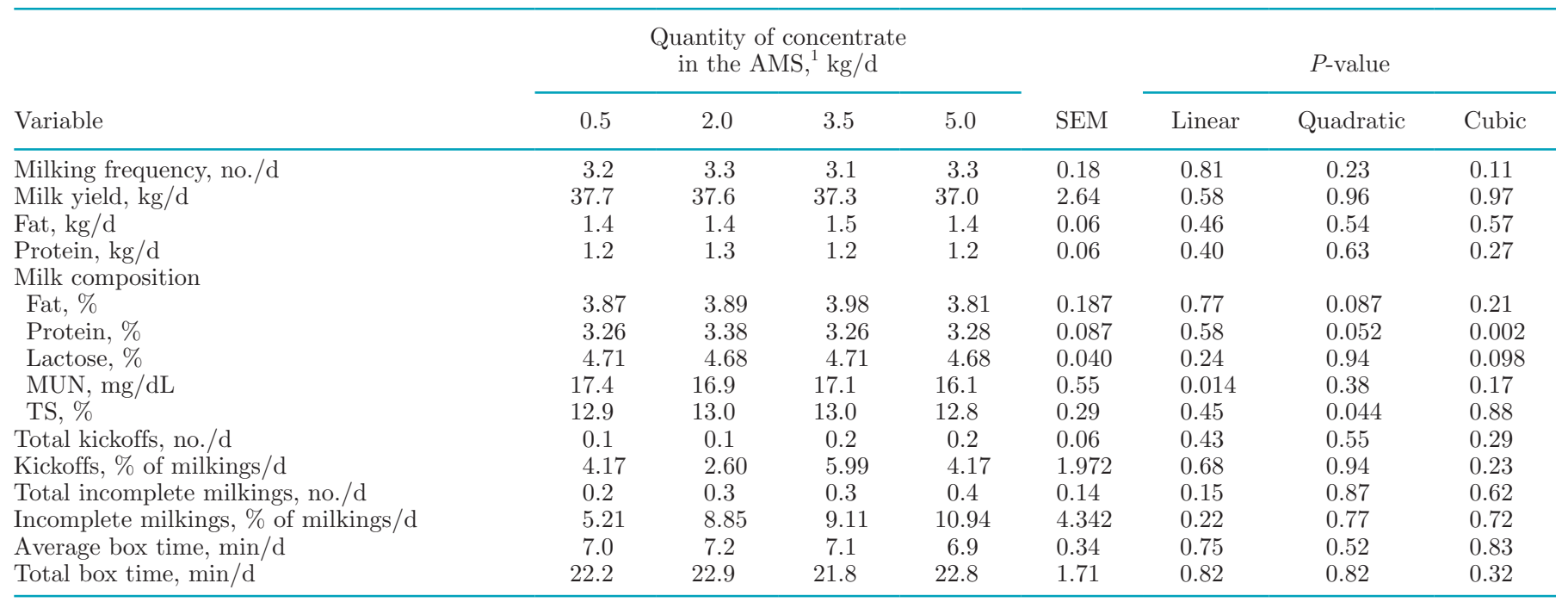

${ }^{1}$ All total diets (AMS concentrate + PMR) were isocaloric. The pellet offered in AMS was the same as the pellet in the PMR and, thus, PMR pellet correspondingly decreased with increasing AMS concentrate.

$\mathrm{kg} / \mathrm{d}$ ) were not different among treatments (Table 5 , $P \geq 0.11$ ); however, MUN linearly decreased as the quantity of concentrate provided in the AMS increased $\left(P_{\text {linear }} \geq 0.014\right)$. Whereas milk and component yields were not affected, the concentration of milk protein was affected cubically $\left(P_{\text {cubic }}=0.002\right)$, with the greatest concentration of milk protein occurring when 2.0 $\mathrm{kg}$ of concentrate was provided in the AMS. Milk fat tended to increase and then decrease as the quantity of AMS concentrate increased $\left(P_{\text {quadratic }}=0.087\right)$, with the greatest concentration of milk fat $(3.98 \%)$ occurring when $3.5 \mathrm{~kg}$ of concentrate was provided in the AMS. Likewise, the concentration of total milk solids was quadratically affected as the quantity of concentrate in the AMS increased $\left(P_{\text {quadratic }}=0.044\right)$, with the greatest concentrations occurring for cows fed 2.0 and $3.5 \mathrm{~kg}$ of AMS concentrate.

The average length of a milking event (box-time; $7.03 \mathrm{~min} / \mathrm{milking})$ and total time spent being milked per day $(22.42 \mathrm{~min} / \mathrm{d})$ were not affected by treatment (Table 5; $P \geq 0.32$ ). Milking events that consisted of at least one quarter being incompletely milked $(8.53 \%)$ or at least one teat cup being kicked-off during a milking event $(4.23 \%)$ were also not different among treatments $(P \geq 0.15)$.

\section{Ruminal Fermentation and Digestibility}

Minimum (5.65), maximum (6.68), and mean (6.18) ruminal $\mathrm{pH}$ were unaffected by treatment $(P \geq 0.12)$.
The duration that ruminal $\mathrm{pH}$ was $<5.8$ was cubically affected, with the greatest duration when fed $2.0 \mathrm{~kg}$ of AMS concentrate (Table 6; $P_{\text {cubic }}=0.033$ ). Total SCFA concentration in ruminal digesta was affected by a cubic response as the quantity of concentrate provided in the AMS increased; total ruminal SCFA concentration was least when $3.5 \mathrm{~kg}$ of concentrate was provided in the AMS (111.62 $\left.\mathrm{m} M, P_{\text {cubic }}=0.046\right)$. Molar proportions of acetate $(62.8 \%)$, propionate $(22.4 \%)$, butyrate $(11.2 \%)$, valerate $(1.4 \%)$, and isovalerate $(1.2 \%)$ were not affected by the quantity of concentrate offered in the AMS $(P \geq 0.13)$. Ruminal concentration of isobutyrate was affected cubically as the amount of concentrate provided in the AMS increased $\left(P_{\text {cubic }}=0.015\right)$, with the greatest concentration of isobutyrate occurring in the 0.5 and 3.5 treatments. The molar proportion of caproate linearly increased as the quantity of AMS concentrate increased $\left(P_{\text {linear }}=0.006\right)$. Ruminal ammonia concentration linearly decreased as allocation of AMS concentrate increased $\left(P_{\text {linear }}=0.023\right)$.

Apparent total-tract digestibility of CP (70.71\%), starch $(95.51 \%)$, and OM $(70.73 \%)$ were not affected by treatment (Table $7 ; P \geq 0.17$ ); however, total-tract digestibility of DM tended to decrease $\left(P_{\text {linear }}=0.096\right)$ and $\mathrm{aNDF}_{\mathrm{OM}}\left(P_{\text {linear }}=0.036\right)$ decreased linearly as AMS concentrate increased, whereas ADF digestibility tended to be quadratically affected by quantity of AMS concentrate $\left(P_{\text {quadratic }}=0.059\right)$. Apparent total-tract digestibility of ether extract increased linearly with increasing AMS concentrate $\left(P_{\text {linear }}<0.001\right)$. 
Table 6. Average daily rumen fermentation results including rumen $\mathrm{pH}$, ammonia and short-chain fatty acid concentration from cows fed increasing quantities of concentrate in the automated milking system (AMS) with a concurrent and equal reduction in the proportion of concentrate in the partial mixed ration $(\mathrm{PMR})$

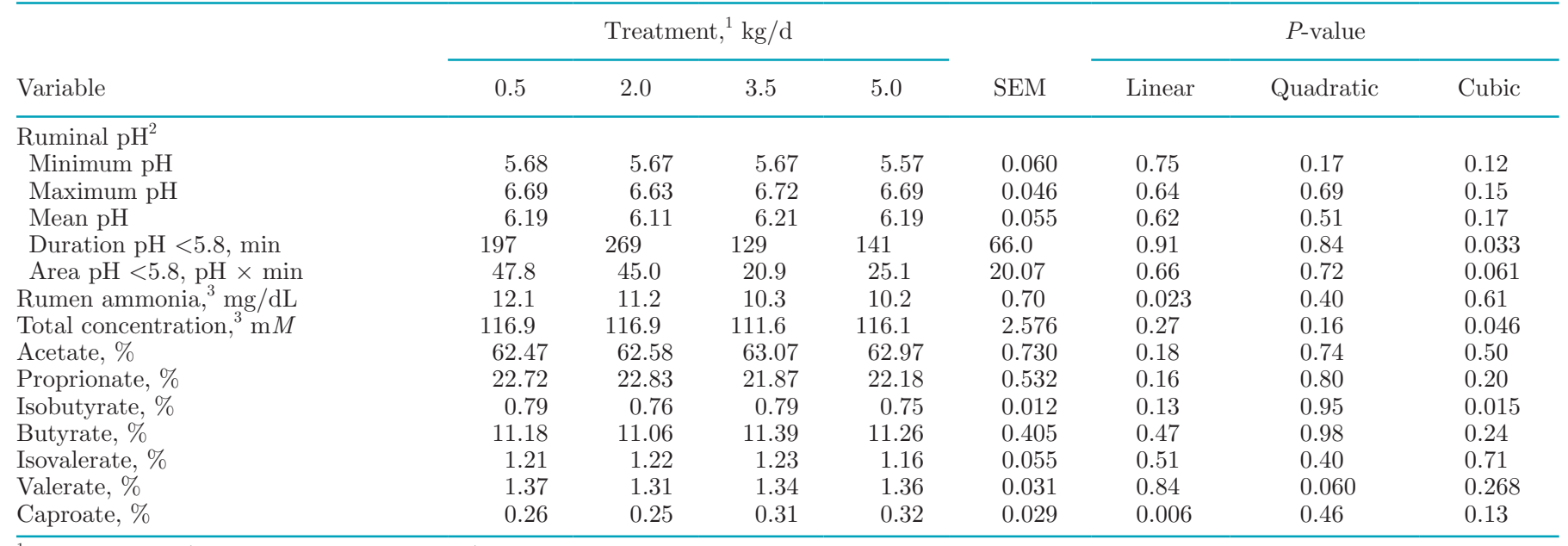

${ }^{1}$ All total diets (AMS concentrate + PMR) were isocaloric. The pellet offered in AMS was the same as the pellet in the PMR and, thus, PMR pellet correspondingly decreased with increasing AMS concentrate.

${ }^{2}$ Ruminal pH measures were collected every 1 min during the 4 -d behavioral measurements for each period. Daily averages are represented.

${ }^{3}$ Rumial ammonia and short-chain fatty acid concentration determination were collected during the 4-d metabolic measurements for each period.

Daily averages are represented.

\section{Activity Budget}

We found no differences $(P \geq 0.14$; Table 8$)$ in the number of lying bouts (10.3 bouts/d), or the average duration of a lying bout (71.2 min). No differences $(P$ $\geq 0.10$ ) among treatments were also observed for total duration cows spent lying each day $(11.6 \mathrm{~h} / \mathrm{d})$.

\section{DISCUSSION}

Researchers have previously evaluated the effect of the quantity of concentrate offered in the AMS when maintaining an isocaloric diet (Bach et al., 2007; Hare et al., 2018) or using the concentrate to increase the nutrient density (Halachmi et al., 2005; Henriksen et al., 2018; Menajovsky et al., 2018). Regardless of the dietary strategy, a consistent response is that increasing the quantity of concentrate offered in the AMS does not necessarily stimulate an improved voluntary attendance to the AMS (Bach et al., 2007; Hare et al., 2018; Menajovsky et al., 2018), milk or milk component yield (Bach et al., 2007; Tremblay et al., 2016; Hare et al., 2018), or DMI (Bach et al., 2007; Henriksen et al., 2018; Menajovsky et al., 2018). Although studies have been conducted to evaluate the effect of concentrate allocation under isocaloric settings, previous studies have been limited to a 2-treatment approach (Bach et al., 2007; Hare et al., 2018); as such, researchers have been unable to adequately characterize the response to increasing AMS concentrate provision. The linear

Table 7. Apparent total-tract digestibility for DM, OM, CP, NDF, ADF, and starch when cows were fed increasing quantities of concentrate in the automated milking system (AMS)

\begin{tabular}{|c|c|c|c|c|c|c|c|c|}
\hline \multirow[b]{2}{*}{ Digestibility } & \multicolumn{4}{|c|}{ Treatment, ${ }^{1} \mathrm{~kg} / \mathrm{d}$} & \multirow[b]{2}{*}{ SEM } & \multicolumn{3}{|c|}{$P$-value } \\
\hline & 0.5 & 2.0 & 3.5 & 5.0 & & Linear & Quadratic & Cubic \\
\hline $\mathrm{OM}, \%$ of DM & 70.82 & 70.82 & 70.42 & 70.05 & 0.752 & 0.17 & 0.67 & 0.83 \\
\hline $\mathrm{CP}, \%$ of $\mathrm{DM}$ & 71.20 & 71.31 & 70.41 & 69.92 & 1.025 & 0.22 & 0.72 & 0.70 \\
\hline Starch, \% of DM & 95.15 & 95.19 & 96.10 & 95.60 & 0.507 & 0.14 & 0.42 & 0.14 \\
\hline $\mathrm{aNDF}_{\mathrm{OM}},{ }^{2} \%$ of DM & 48.34 & 48.36 & 47.22 & 46.31 & 1.140 & 0.036 & 0.51 & 0.66 \\
\hline
\end{tabular}

${ }^{1}$ All total diets (AMS concentrate + partial mixed ration) were isocaloric. The pellet offered in AMS was the same as the pellet in the partial mixed ration and, thus, partial mixed ration pellet correspondingly decreased with increasing AMS concentrate.

${ }^{2} \mathrm{aNDF}_{\mathrm{OM}}=\mathrm{NDF}$ treated with $\alpha$-amylase and sodium sulfite and corrected for ash content. 
Table 8. Lying budgets of cows fed increasing quantities of concentrate in the automated milking system (AMS) with a concurrent and equal reduction the proportion of concentrate in the partial mixed ration (PMR)

\begin{tabular}{|c|c|c|c|c|c|c|c|c|}
\hline \multirow[b]{2}{*}{ Variable $^{1}$} & \multicolumn{4}{|c|}{ Quantity of concentrate in the $\mathrm{AMS},{ }^{2} \mathrm{~kg} / \mathrm{d}$} & \multirow[b]{2}{*}{ SEM } & \multicolumn{3}{|c|}{$P$-value } \\
\hline & 0.5 & 2.0 & 3.5 & 5.0 & & Linear & Quadratic & Cubic \\
\hline Lying bouts, no./d & 10.8 & 10.6 & 9.9 & 9.9 & 0.91 & 0.45 & 0.85 & 0.22 \\
\hline Average lying bout duration, $\mathrm{min} / \mathrm{d}$ & 65.1 & 74.8 & 66.9 & 77.8 & 6.31 & 0.14 & 0.89 & 0.078 \\
\hline
\end{tabular}

${ }^{1}$ Variables were calculated using the procedure outlined by Zobel and Chapinal (2013) and coding of Ledgerwood et al. (2010).

${ }^{2}$ All total diets (AMS concentrate + PMR) were isocaloric. The pellet offered in AMS was the same as the pellet in the PMR and, thus, PMR pellet correspondingly decreased with increasing AMS concentrate.

increase in AMS concentrate allocation, along with a concurrent and equal reduction in concentrate provision in the PMR in the present study, had no effect on total DMI, visits to the AMS, or milk and milk component yields. These findings suggest that when dietary nutrient composition is equal, increasing AMS concentrate provision (at the expense of concentrate provision in the PMR) in a feed-first guided traffic design does not affect production responses. Findings in the present study are generally supported by previous research, including Bach et al. (2007) and Hare et al. (2018).

A challenge with most previous AMS studies is that the targeted concentrate consumption in the AMS was not achieved (Halachmi et al., 2005; Bach et al., 2007; Henriksen et al., 2018). In the current study, the computer-programmed concentrate allocation was slightly greater than the targeted concentrate consumption to ensure consumption was similar to the target. For example, the programmed values of $0.51(\mathrm{SD}=0.014)$, $2.02(\mathrm{SD}=0.041), 3.52(\mathrm{SD}=0.085)$, and $5.03(\mathrm{SD}$ $=0.142) \mathrm{kg}$ of $\mathrm{DM}$ were entered into the computer software system to achieve $0.50,2.00,3.49$, and 4.93 $\mathrm{kg} / \mathrm{d}$ of DM consumed in the AMS. In addition to requiring a computer-programmed AMS allocation that exceeded the target consumption, feeding greater quantities of AMS concentrate increased variation in AMS concentrate intake among days. In fact, the standard deviation for the mean concentrate intake among days increased from 0.06 to $0.85 \mathrm{~kg} / \mathrm{d}$ when the AMS concentrate target increased from 0.5 to $5.0 \mathrm{~kg} / \mathrm{d}$. We found only 1 previous study that reported variability in AMS concentrate intake among days (Menajovsky et al., 2018). In that study, Menajovsky et al. (2018) reported that when $6.0 \mathrm{~kg}$ of concentrate was provided in the AMS, the standard deviation for mean AMS concentrate intake among days was $0.85 \mathrm{~kg} / \mathrm{d}$ and was greater than when compared with feeding $2.0 \mathrm{~kg}$ of concentrate in the AMS (SD =0.25). Although not presented in the publication of Hare et al. (2018), data we obtained from the authors demonstrate greater variation in AMS concentrate intake among days when
$5.0 \mathrm{~kg}(\mathrm{SD}=0.78)$ were offered in comparison to $0.5 \mathrm{~kg}$ $(\mathrm{SD}=0.07)$ of concentrate in the AMS. The variability in AMS concentrate intake among days when providing larger quantities of concentrate in the AMS is expected to reduce consistency of nutrient intake and uniformity in the diet consumed.

The majority of studies focusing on AMS feeding management have only reported AMS concentrate intake (Halachmi et al., 2005; Tremblay et al., 2016), whereas a few have reported both AMS and PMR intake (Bach et al., 2007; Hare et al., 2018; Henriksen et al., 2018; Menajovsky et al., 2018). In the present study, total DMI did not differ among treatments when considering both AMS concentrate and PMR intake. The lack of response for total DMI occurred as cows linearly decreased PMR intake in response to a linear increase in AMS concentrate intake. In fact, we observed a decrease in PMR DMI by $0.97 \mathrm{~kg}$ of DM for every 1-kg DM increase in AMS concentrate intake.

Previous studies reporting substitution ratios (the reduction in PMR intake for every $1 \mathrm{~kg}$ increase in AMS concentrate) in AMS do not appear to be consistent, and ratios as low as 0.84 (Menajovsky et al., 2018) and as great as 1.58 (Hare et al., 2018) have been reported. In another study (Bach et al., 2007), a reduction of 1.14 $\mathrm{kg}$ of DM in PMR intake was observed for every 1-kg DM increase in AMS concentrate consumed. Henriksen et al. (2018) reported that the slope reduction for PMR intake caused by an increase in AMS concentrate intake was not equivalent to the slope increase for PMR intake when AMS concentrate intake decreased. Whereas a nearly $1: 1$ substitution rate was observed in the present study, the inability to predict the substitution rate precludes the ability to impose precision feeding management strategies when simply altering the quantity of a single pellet.

Numerous factors influence the substitution rate, including the quantity of concentrate provided, type of roughage, and type of concentrate (Faverdin et al., 1991; Jensen et al., 2015). Generally, providing more concentrate causes a greater reduction in roughage (Lamb et al., 1973; Vérité and Journet, 1973; Oster- 
gaard, 1979) with a response that is nonlinear (Jensen et al., 2015). Increasing the energy content of the concentrate and the quality of the forage may also increase the substitution rate (Faverdin et al., 1991; Jensen et al., 2015). However, other studies have demonstrated no difference in substitution rates with diets using cereals or dried sugar beet as the concentrate component of the diet (Castle et al., 1981; Dulphy et al., 1987). The lack of difference for the total quantity of concentrate provided when considering the AMS and PMR, and considering we did not change the composition of the pellet regardless of where it was offered (AMS or PMR), likely explains why the substitution rate was nearly $1: 1$.

In pasture-based studies, a reduction in pasture DMI is often observed when cows are provided supplements (Kellaway and Porta, 1993). The substitution effect is believed to explain variation in the response for milk yield when provided with supplementation (kilogram of milk/kilogram of supplement; Bargo et al., 2003). However, relative to grazing scenarios, where cows are provided concentrate supplementation, the substitution rates observed in AMS are relatively high and, in some cases, represent the potential for negative effects on DMI (Bargo et al., 2003). In addition to the dietary factors listed above, it has been hypothesized that the substitution rates and variation in milk responses may be influenced by cow genetics, individual milk production, stage of lactation, energy balance (Murdock and Hodgson, 1969; Donker and MacClure, 1982; Bargo et al., 2003), parity, and day of gestation (Faverdin et al., 1991; Jensen et al., 2015).

As stated above, understanding how cows adjust their PMR feeding behavior is important for feeding management in AMS. Hare et al. (2018) and Menajovsky et al. (2018) reported that increasing the quantity of concentrate in the AMS reduces PMR consumption and alters the sorting behavior, eating rate, and meal size of the PMR. For example, Hare et al. (2018) reported that when $5.0 \mathrm{~kg}$ of concentrate was provided in the AMS, cows sorted for particles retained on the 8-mm sieve and against particles retained on the pan when compared with $0.5 \mathrm{~kg}$ of concentrate allocated in the AMS. The formulation of PMR for cows fed $5.0 \mathrm{~kg}$ of concentrate in the AMS resulted in a greater F:C (58:42) of the PMR compared with those cows fed 0.5 $\mathrm{kg}$ of concentrate in the AMS (49:51; Hare et al., 2018). Thus, those researchers detected greater PMR meal durations, feeding rates, and meal sizes when cows were fed $5.0 \mathrm{~kg}$ of concentrate in the AMS and, by default, a PMR with a greater proportion of forage. Menajovsky et al. (2018) reported that when $6.0 \mathrm{~kg}$ of concentrate was offered in the AMS, cows discriminated more against particles retained on the $8-\mathrm{mm}$ sieve than when fed 2.0 $\mathrm{kg}$ of concentrate in the AMS. Moreover, feeding 2.0 $\mathrm{kg}$ of concentrate in the AMS increased sorting against particles retained in the pan. Menajovsky et al. (2018) also observed shorter daily eating durations ( $\mathrm{min} / \mathrm{d}$ ) for cows fed a greater quantity of concentrate in the AMS; however, no other differences in PMR feeding behaviors were observed. In the present study, increasing the quantity of concentrate in the AMS (and correspondingly decreasing the concentrate in the PMR) resulted in selective avoidance for particles retained on the top sieve of the PSPS. In addition, a linear increase in sorting against particles collected on the pan was observed as the proportion of concentrate in the AMS decreased. The sorting responses corresponded to a linear increase in meal duration and a reduction in eating rate as the quantity of concentrate consumed in the AMS increased. The increased meal duration and reduced eating rate likely provided a mechanism to allow for greater sorting. It is not clear why, from a nutritional context, cows in the present study increased sorting against long particles and reduced their sorting against fine particles as the proportion of AMS concentrate increased. However, similar to that found in DeVries et al. (2007), the PMR of the $0.5-\mathrm{kg}$ treatment contained the lowest F:C, thereby allowing cows to have a greater ability to sort against the long particles. Such sorting behavior can be expected to further alter the composition of the diet consumed relative to that formulated and delivered, which has implications for feeding management (Miller-Cushon and DeVries, 2017). Thus, feeding strategies must consider both the AMS and PMR, as the AMS concentrate provision influences feeding behaviors associated with the PMR.

As AMS feeding strategies impose a component feeding system, understanding the effect of the site where concentrate is offered (AMS vs. PMR) on ruminal fermentation is critical. Only 1 previous study has reported ruminal $\mathrm{pH}$, SCFA concentrations, and ruminal ammonia concentrations for cows milked in AMS (Menajovsky et al., 2018). In the present study, we did not observe any treatment effects on the minimum, mean, or maximum ruminal $\mathrm{pH}$. The lack of response was surprising given the changes in the quantity of concentrate offered in the AMS and PMR, the changes observed for feeding behavior (meal duration and eating rate), and PMR sorting characteristics. However, when considering the AMS and PMR components collectively, the dietary treatments were formulated to be equivalent, suggesting that detectable but subtle changes in eating patterns do not necessarily affect ruminal $\mathrm{pH}$ when total DMI is consistent. Moreover, the maximum meal size offered in the AMS was $2.5 \mathrm{~kg}$. It is likely that constraining the maximum meal size limits the effect of the dietary concentrate delivered in the AMS on ruminal fermentation (Menajovsky et al., 2018). In 
support of the present study, Maekawa et al. (2002) observed no differences in ruminal $\mathrm{pH}$ when comparing component feeding to TMR feeding when the diet composition was the same; however, those authors did conclude that component feeding is likely to alter the $\mathrm{F}: \mathrm{C}$ of the consumed diet, allowing cows to consume more concentrate than was intended. Menajovsky et al. (2018) reported that increasing the dietary energy density by reducing the $\mathrm{F}: \mathrm{C}$ of the PMR reduces ruminal $\mathrm{pH}$, whereas increasing the dietary energy density by increasing the AMS concentrate allocation did not affect the ruminal $\mathrm{pH}$ response. This suggests that, with the maximum meal size imposed in the AMS, changing the site of concentrate allocation would likely not affect ruminal $\mathrm{pH}$.

Although ruminal $\mathrm{pH}$ was not affected, ruminal SCFA concentration was least when $3.5 \mathrm{~kg}$ of concentrate was provided in the AMS. No clear explanation justifies the change in ruminal SCFA concentration, but it may be possible that the response is related to differences in activity patterns among cows and treatments. In the present study, ruminal digesta samples were collected in attempt to obtain a good representation over a $24-\mathrm{h}$ cycle; however, the timing of the PMR meals and AMS visits relative to the timing of sampling may not have been consistent among treatments and periods, as the day-to-day movement patterns of cows varies. Thus, changes in ruminal SCFA concentrations may be partially affected by activity patterns of cows in addition to the dietary treatments.

Ruminal ammonia concentrations decreased linearly with increasing AMS concentrate provision. As with total ruminal SCFA concentrations, we cannot rule out the fact that activity patterns may have influenced this response. In a previous study, Menajovsky et al. (2018) reported no difference in ruminal ammonia concentrations across treatments when different quantities of concentrate were allocated in the AMS. However, in the present study, total-tract digestibility of DM, $\mathrm{aNDF}_{\mathrm{OM}}$, and $\mathrm{ADF}$ tended to be reduced and ether extract linearly increased with increasing amounts of concentrate provided in the AMS, supporting the concept that ruminal fermentation may have been altered. In addition, despite total dietary formulations in the current study being equivalent, we observed increased variability for AMS concentrate intake among days as the allocation of concentrate in the AMS increased. We hypothesized that this linear increase in variability of AMS concentrate intake and changes in sorting behavior of the PMR influenced ruminal ammonia concentrations and negatively affected $\mathrm{DM}, \mathrm{aNDF}_{\mathrm{OM}}$, and $\mathrm{ADF}$ digestibility. We were unable to explain the cause for improved ether extract digestibility.
The results for reduced digestibility of $\mathrm{DM}, \mathrm{aNDF}_{\mathrm{OM}}$, and $\mathrm{ADF}$ are not consistent with the literature when supplementation is provided, at least when the supplement has a greater nutrient density than the basal forage or PMR (Bargo et al., 2003). Menajovsky et al. (2018) reported greater DM digestibility when $6.0 \mathrm{~kg}$ of concentrate was provided in the AMS, whereas ADF digestibility was greatest when $2.0 \mathrm{~kg}$ of concentrate was allocated in the AMS and ether extract and aN$\mathrm{DF}_{\mathrm{OM}}$ were not different among treatments. Although the digestibility responses observed in the present study were inconsistent with Menajovsky et al. (2018) and grazing applications (Bargo et al., 2003), those studies generally imposed diets that increased the total energy density, thereby explaining the improvement in digestibility. Previous research has emphasized that the consumption of large amounts of concentrate in the AMS consistently influences the feeding behavior and feed intake of the PMR (Hare et al., 2018; Menajovsky et al., 2018) and may also influence the rate and extent of NDF digestibility (Miron et al., 2004; Halachmi et al., 2005). Although we cannot attribute the reduction in $\mathrm{DM}, \mathrm{aNDF}_{\mathrm{OM}}$, and $\mathrm{ADF}$ digestibility to low ruminal $\mathrm{pH}$, we speculated that the component feeding strategy imposed in AMS and the resultant changes in feeding behavior may affect ruminal residence time and, hence, digestibility. To date, factors affecting the digestibility of nutrients for cows milked with AMS are relatively unexplored and further investigation is necessary.

Finally, we observed that altering AMS concentrate allocation did not affect AMS attendance, milk or milk component yields, or lying behavior. Given the diets were equivalent in nutrient supply, it is not surprising that milk and milk component yields were not different. These results agree with previous studies in both freeflow (Bach et al., 2007) and guided-flow barn designs (Hare et al., 2018; Menajovsky et al., 2018). In a retrospective study, Tremblay et al. (2016) indicated that increasing the quantity of concentrate in the AMS was associated with reduced milk yield. Thus, the data in the present study were consistent with other published findings using isoenergetic diets with varying concentrate allocation in the AMS, supporting the hypothesis that greater concentrate allocations in the AMS do not positively influence milk production parameters. However, this contradicts current AMS feeding management recommendations, where dietary energy density is increased with increasing AMS pellet allocation (Salfer and Endres, 2014), and a recent study by Henriksen et al. (2018).

In addition, we observed no effect of AMS concentrate allocation on the yield of milk fat or protein, consistent with Menajovsky et al. (2018) and Bach et al. (2007). 
However, we observed changes in milk composition, with milk fat concentration being greatest when fed $3.5 \mathrm{~kg}$ of concentrate in the AMS and milk protein being greatest when fed $2.0 \mathrm{~kg}$ of concentrate. Considering that component yield was not affected, these changes are difficult to explain. Hare et al. (2018) reported no differences in either milk fat, protein, or TS concentrations when the total diet nutrient composition did not differ. In contrast, Menajovsky et al. (2018) reported greater milk fat concentration and a tendency for greater milk protein concentration when $2.0 \mathrm{~kg}$ of concentrate was provided in the AMS relative to $6.0 \mathrm{~kg}$ of concentrate in the AMS without a concurrent change in energy density of the PMR. Moreover, in the present experiment, MUN was reduced as the concentrate allocated in the AMS increased, corresponding to the linear reduction in ruminal ammonia concentration. Menajovsky et al. (2018) also demonstrated reduced MUN when $6.0 \mathrm{~kg}$ of concentrate was provided in the AMS compared with $2.0 \mathrm{~kg}$. As with the treatment responses associated with total SCFA and rumen ammonia concentration, the variability of AMS concentrate intake among days in addition to the sorting behavior associated with the PMR likely helps explain these responses.

\section{CONCLUSIONS}

For cows in a feed-first guided-traffic flow design, increasing the quantity of concentrate in the AMS while maintaining total dietary nutrient density by altering the PMR does not affect voluntary attendance to the AMS, milk yield, or milk component yield. Feeding greater quantities of concentrate in the AMS increases the day-to-day variation in AMS concentrate intake, thereby reducing the ability to implement precision feeding strategies. Increasing the quantity of concentrate offered in the AMS, and consequently decreasing the concentrate in the PMR, also affects PMR sorting and feeding behavior and may reduce total-tract DM, $\mathrm{aNDF}_{\mathrm{OM}}$, and $\mathrm{ADF}$ digestibility. Therefore, feeding smaller quantities $(<5 \mathrm{~kg})$ of concentrate in the AMS should minimize variability in nutrient intake and allow cows to achieve target AMS consumption while not affecting AMS visits and the yield of milk and milk components.

\section{ACKNOWLEDGMENTS}

The authors acknowledge the staff of the Rayner Dairy Research and Teaching Facility (Saskatoon, SK, Canada) for allowing us to use their animals and facility, as well as the Alberta Livestock and Meat Agency Ltd. (Edmonton, AB, Canada), Alberta Milk (Edmonton, AB, Canada), the Saskatchewan Ministry of Ag- riculture, Agriculture Development Fund (Regina, SK, Canada), the Dairy Farmers of Manitoba (Winnipeg, MB, Canada), and SaskMilk (Regina, SK, Canada) for providing the funding for this project.

\section{REFERENCES}

AOAC International. 2000. Official Method of Analysis. 15th ed. AOAC International, Arlington, VA.

AOAC International. 2006. Official Method of Analysis. 18th ed. AOAC International, Arlington, VA.

Bach, A., and V. Cabrera. 2017. Robotic milking: Feeding strategies and economic returns. J. Dairy Sci. 100:7720-7728. https://doi .org/10.3168/jds.2016-11694.

Bach, A., C. Iglesias, S. Calsamiglia, and M. Devant. 2007. Effect of amount of concentrate offered in automatic milking systems on milking frequency, feeding behavior, and milk production of dairy cattle consuming high amounts of corn silage. J. Dairy Sci. 90:5049-5055. https://doi.org/10.3168/jds.2007-0347.

Bargo, F., L. D. Muller, E. S. Kolver, and J. E. Delahoy. 2003. Invited review: Production and digestion of supplemented dairy cows on pasture. J. Dairy Sci. 86:1-42. https://doi.org/10.3168/jds.S0022 -0302(03)73581-4.

Castle, M. E., M. S. Gill, and J. N. Watson. 1981. Silage and milk production: a comparison between barley and dried sugar-beet pulp as silage supplements. Grass Forage Sci. 36:319-324. https://doi.org/ 10.1111/j.1365-2494.1981.tb01569.x.

Cumberland Valley Analytical Services Inc. 2018. Invitro NDF Analysis. CVAS Cumberland Valley Analytical Services. Waynesboro, PA. Accessed Feb. 1, 2017. http://www.foragelab.com/Lab -Services/Forage-and-Feed/Invitro-NDF-Analysis.

de Jong, W., A. Finnema, and D. J. Reinemann. 2003. Survey of management practices of farms using automatic milking systems in North America. ASAE Annual International Meeting Technical Paper No. 033017. Am. Soc. Agric. Biol. Eng., St. Joseph, MI.

DeVries, T. J., K. A. Beauchemin, and M. A. G. Von Keyserlingk. 2007. Dietary forage concentration affects the feed sorting behavior of lactating dairy cows. J. Dairy Sci. 90:5572-5579. https://doi .org/10.3168/jds.2007-0370.

DeVries, T. J., M. A. G. von Keyserlingk, D. M. Weary, and K. A. Beauchemin. 2003a. Measuring the feeding behavior of lactating dairy cows in early to peak lactation. J. Dairy Sci. 86:3354-3361. https://doi.org/10.3168/jds.S0022-0302(03)73938-1.

Donker, J. D., and F. A. MacClure. 1982. Responses of milking cows to amounts of concentrate in rations. J. Dairy Sci. 65:1189-1204. https://doi.org/10.3168/jds.S0022-0302(82)82330-8.

Dulphy, J. P., J. P. Andrieu, and J. Rouel. 1987. Effet de la nature de l'aliment concentré sur les performances de vaches laitieres recevant une ration à base de foin. Bull Tech. 56:43-47.

Faverdin, P., J. P. Dulphy, J. B. Coulon, R. Vérité, J. P. Garel, J. Rouel, and B. Marquis. 1991. Substitution of roughage by concentrates for dairy cows. Livest. Prod. Sci. 27:137-156. https://doi .org/10.1016/0301-6226(91)90092-5.

Fawcett, J. K., and J. E. Scott. 1960. A rapid and precise method for the determination of urea. J. Clin. Pathol. 13:156-159. https://doi .org/10.1136/JCP.13.2.156.

Halachmi, I., S. Ofir, and J. Miron. 2005. Comparing two concentrate allowances in an automatic milking system. Anim. Sci. 80:339-343. https://doi.org/10.1079/ASC40480339.

Hall, M. B., W. H. Hoover, J. P. Jennings, and T. K. Miller Webster. 1999. A method for partitioning neutral detergent-soluble carbohydrates. J. Sci. Food Agric. 79:2079-2086.

Hare, K., T. DeVries, K. Schwartkopf-Genswein, and G. B. Penner. 2018. Does the location of concentrate provision affect voluntary visits, and milk and milk component yield for cows in an automated milking system? Can. J. Anim. Sci. 98:399-404. https://doi .org/10.1139/cjas-2017-0123.

Henriksen, J. C. S., L. Munksgaard, and M. R. Weisbjerg. 2018. Short-term responses in production and behavior during periods 
of change in concentrate allowance for dairy cows. J. Dairy Sci. 101:7942-7953. https://doi.org/10.3168/jds.2018-14624.

Jensen, L. M., N. I. Nielsen, E. Nadeau, B. Markussen, and P. Nørgaard. 2015. Evaluation of five models predicting feed intake by dairy cows fed total mixed ration. Livest. Sci. 176:91-103. https:/ /doi.org/10.1016/j.livsci.2015.03.026.

Kellaway, R., and S. Porta. 1993. Feeding Concentrates Supplements for Dairy Cows. Dairy Research and Development Corporation, Melbourne, Australia.

Khorasani, G. R., E. K. Okine, and J. J. Kennelly. 1996. Forage source alters nutrient supply to the intestine without influencing milk yield. J. Dairy Sci. 79:862-872. https://doi.org/10.3168/jds.S0022 -0302(96)76435-4.

Kononoff, P. J., A. J. Heinrichs, and D. R. Buckmaster. 2003. Modification of the Penn State Forage and Total Mixed Ration Particle Separator and the effects of moisture content on its measurements. J. Dairy Sci. 86:1858-1863. https://doi.org/10.3168/jds.S0022 -0302(03)73773-4.

Lamb, R. C., G. E. Stoddard, C. H. Michelsen, M. J. Anderson, and D. R. Waldo. 1973. Response to concentrates containing two percent of protein fed at four rates for complete lactations. J. Dairy Sci. 57:811-815. https://doi.org/10.3168/jds.S0022-0302(74)84969-6.

Ledgerwood, D. N., C. Winckler, and C. B. Tucker. 2010. Evaluation of data loggers, sampling intervals, and editing techniques for measuring the lying behavior of dairy cattle. J. Dairy Sci. 93:51295139. https://doi.org/10.3168/jds.2009-2945.

Leonardi, C., and L. E. Armentano. 2003. Effect of quantity, quality, and length of alfalfa hay on selective consumption by dairy cows. J. Dairy Sci. 86:557-564. https://doi.org/10.3168/jds.S0022 $-0302(03) 73634-0$

Macdonald, P. D. M., and P. E. J. Green. 1988. User's guide to program MIX: An interactive program for fitting mixtures of distributions. Release 2.3. Accessed Jan. 15, 2017. https://ms.mcmaster .ca/peter/mix/MIX23_Users_Guide.pdf.

Maekawa, M., K. A. Beauchemin, and D. A. Christensen. 2002. Effect of concentrate level and feeding management on chewing activities, saliva production, and ruminal $\mathrm{pH}$ of lactating dairy cows. J. Dairy Sci. 85:1165-1175. https://doi.org/10.3168/jds.S0022 $-0302(02) 74179-9$.

Menajovsky, S. B., C. E. Walpole, T. J. DeVries, K. S. SchwartzkopfGenswein, M. E. Walpole, and G. B. Penner. 2018. The effect of the forage-to-concentrate ratio of the partial mixed ration and the quantity of concentrate in an automatic milking system for lactating Holstein cows. J. Dairy Sci. 101:9941-9953. https://doi.org/10 $.3168 /$ jds.2018-14665.

Miller-Cushon, E. K., and T. J. DeVries. 2017. Feed sorting in dairy cattle: Causes, consequences, and management. J. Dairy Sci. 100:4172-4183. https://doi.org/10.3168/jds.2016-11983.

Miron, J., E. Yosef, M. Nikbachat, A. Zenou, E. Maltz, I. Halachmi, and D. Ben-Ghedalia. 2004. Feeding behavior and performance of dairy cows fed pelleted nonroughage fiber byproducts. J. Dairy Sci. 87:1372-1379. https://doi.org/10.3168/jds.S0022-0302(04)73286 $-5$.

Murdock, F. R., and A. S. Hodgson. 1969. Input-output relationships of cows fed two types of roughage and two levels of concentrate during complete lactations. J. Dairy Sci. 52:1961-1972. https://doi .org/10.3168/jds.S0022-0302(69)86881-5.

National Forage Testing Association (NFTA). 2006. NFTA method 2.1.4: Dry matter by oven drying for $3 \mathrm{hr}$ at $105^{\circ} \mathrm{C}$. Accessed Feb. 1, 2017. https://docs.wixstatic.com/ugd/24f64f _76e09765aa4c4550acb4d845e4d446dd.pdf.

Ostergaard, V. 1979. Food intake. Pages 37-67 in Strategies for Concentrate Feeding to attain Optimum Feeding Level in High Yielding Dairy Cows. National Institute of Agriculture Science, Copenhagen, Denmark.

Penner, G. B., K. A. Beauchemin, and T. Mutsvangwa. 2006. An evaluation of the accuracy and precision of a stand-alone submersible continuous ruminal $\mathrm{pH}$ measurement system. J. Dairy Sci. 89:2132-2140. https://doi.org/10.3168/jds.S0022-0302(06)72284 $-6$.

Penner, G. B., K. A. Beauchemin, and T. Mutsvangwa. 2007. Severity of ruminal acidosis in primiparous Holstein cows during the periparturient period. J. Dairy Sci. 90:365-375. https://doi.org/10 .3168/jds.S0022-0302(07)72638-3.

Prescott, N. B., T. T. Mottram, and A. J. F. Webster. 1998. Relative motivations of dairy cows to be milked or fed in a Y-maze and an automatic milking system. Appl. Anim. Behav. Sci. 57:23-33. https://doi.org/10.1016/S0168-1591(97)00112-3.

Salfer, J., and M. Endres. 2014. How are robotic milking dairies feeding their cows? Pages 77-80 in Proc. 4-State Dairy Nutrition Conference, Dubuque, IA.

Tolkamp, B. J., D. J. Allcroft, E. J. Austin, B. L. Nielsen, and I. Kyriazakis. 1998. Satiety splits feeding behaviour into bouts. J. Theor. Biol. 194:235-250. https://doi.org/10.1006/jtbi.1998.0759.

Tremblay, M., J. P. Hess, B. M. Christenson, K. K. McIntyre, B. Smink, A. J. van der Kamp, L. G. de Jong, and D. Döpfer. 2016. Factors associated with increased milk production for automatic milking systems. J. Dairy Sci. 99:3824-3837. https://doi.org/10 $.3168 /$ jds.2015-10152.

Tse, C., H. W. Barkema, T. J. DeVries, J. Rushen, and E. A. Pajor. 2017. Effect of transitioning to automatic milking systems on producers' perceptions of farm management and cow health in the Canadian dairy industry. J. Dairy Sci. 100:2404-2414. https://doi .org/10.3168/jds.2016-11521.

Vérité, R., and M. Journet. 1973. Complémentation des rations à base d'ensilage de maïs en début de lactation. Bull. Tech. 11:41-46.

Wagner-Storch, A. M., and R. W. Palmer. 2003. Feeding behavior, milking behavior, and milk yields of cows milked in a parlor versus an automatic milking system. J. Dairy Sci. 86:1494-1502. https:// doi.org/10.3168/jds.S0022-0302(03)73735-7.

Wildman, E. E., I. G. M. Jones, P. E. Wagner, and R. L. Boman. 1982. A dairy cow body condition scoring system and its relationship to selected production characteristics. J. Dairy Sci. 65:495-501.

Zobel, G., and N. Chapinal. 2013. UBC Animal Welfare Program : SOP - HOBO Data Loggers 1-23. University of British Columbia. Accessed Nov. 1, 2015. http://awp.landfood.ubc.ca/files/2013/11/ SOP-HOBO-Datalogger-november-2013.pdf. 